\title{
Regeneration of inner ear sensory epithelium using stem cells: state of art
}

\author{
A R Fetoni*, G Paludetti \\ From de Senectute: Age and Health Forum \\ Catanzaro, Italy. 5-7 December 2009
}

Contemporary research efforts have provided new insight into the processes underlying common hearing impairments include aging, genetic defects, and environmental stress such as excessive noise (NIHL) or chemotherapeutic drugs. The primary cause of hearing impairment involves the death of sensory cells (hair cells) and neurons in the cochlea which are irreplaceable in mammmals. Rehabilitative measures have traditionally been based on technical solutions: hearing aids and cochlear implants that can minimize the social impact of impairment, however the challenge for a successful hearing rehabilitation is definitely the prevention of cell death or regeneration of the sensorineural cells and neurons after cochlear damage. Addressing experimentally the first issue, we have shown that noise exposure and ototoxic drugs lead to apoptosis and by using neurotrophic factors and anti-apoptotic drugs as well as antioxidants, we have developed several therapeutic approaches of protection thus limiting the damage to the inner ear [1-3].

One of the most exciting areas involving hair-cell regeneration concerns regeneration of hair cells with the use of stem cells. The discovery of both adult and embryonic stem cells in the cochlea and evidence that they can be converted into hair cells raise hope for the development of stem-cell based treatment regimes to regenerate damaged cochlear components. Potential cell sources for inner ear transplantation include fetal dorsal root ganglion cells, neural progenitor cells, stem or progenitor cells isolated from inner ear, immortalized auditory neuroblast cells, embryonic stem cells (ESCs) and their derived neuronal cells, and marrow stromal cells and finally stem cells arising from amniotic fluid and placenta and olfactory progenitors [3,4]. Principal obstacles for the clinical application remain the effects of

Institute of Otolaryngology, Catholic Univesity of Rome, Italy immunosuppression, induced-carcinogenesis and teratoma formation observed in the experimental models $[3,4]$.

Published: 19 May 2010

\section{References}

1. Fetoni RA, Piacentini R, Fiorita A, Paludetti G, Troiani D: Water-soluble Coenzyme Q10 formulation (Q-ter) promotes outer hair cell survival in a guinea pig model of noise induced hearing loss (NIHL). Brain Res 2009, 1257:108-16.

2. Fetoni AR, Ferraresi A, Greca CL, Rizzo D, Sergi B, Tringali G, Piacentini R, Troiani D: Antioxidant protection against acoustic trauma by coadministration of idebenone and vitamin E. Neuroreport. 2008, 19:277-81.

3. Wei $D$, Yamoah EN: Regeneration of the mammalian inner ear sensory epithelium. Curr Opin Otolaryngol Head Neck Surg. 2009, 17:373-80.

4. Brigande SV, Heller S: Quo vadis, hair cell regeneration? Nat Neurosci. 2009, 12:679-85.

\section{doi:10.1186/1471-2318-10-S1-L9}

Cite this article as: Fetoni and Paludetti: Regeneration of inner ear sensory epithelium using stem cells: state of art. BMC Geriatrics 2010 10(Suppl 1):L9.

\section{Submit your next manuscript to BioMed Central and take full advantage of: \\ - Convenient online submission \\ - Thorough peer review \\ - No space constraints or color figure charges \\ - Immediate publication on acceptance \\ - Inclusion in PubMed, CAS, Scopus and Google Scholar \\ - Research which is freely available for redistribution

